\title{
MEDIA KARTU KOSA KATA DAN PEMBELAJARAN BAHASA DALAM MENUNJANG PROFESIONALISME GURU
}

\author{
Nancy Angelia Purba ${ }^{1}$, Restio Sidebang ${ }^{2}$ \\ ${ }^{1}$ Universitas HKBP Nommensen Pematangsiantar \\ ${ }^{2}$ Universitas Quality \\ Email: ${ }^{1}$ nancypurba27@gmail.com, ${ }^{2}$ restiosidebang@gmail.com
}

\begin{abstract}
ABSTRAK
Media kartu kosa kata dan Pembelajaran bahasa. Media pembelajaran memegang peranan penting dalam proses belajar mengajar di kelas. Proses pembelajaran itu tidak lepas dari penggunaan media digunakan oleh guru secara kontiunitas dan komprehensif tentunya akan menunjang profesionalisme guru, terkhusus guru bahasa. Dibutuhkan keterampilan seorang guru bahasa dalam menggunakan media kartu kosa kata agar pembelajaran yang menarik, inovatif dan menyenangkan. Dibutuhkan kesadaran guru senantiasa dan akrab dengan media pembelajaran. Dengan terampil menggunakan media pembelajaran kartu kosa kata dalam proses belajar mengajar merupakan salah satu menunjang profesionalisme guru bahasa terkhusus di tingkat usia dini dan sekolah dasar. Jika dipahami dengan baik, sesungguhnya media kartu kosa kata menjadi jawaban bagi guru bahasa untuk meningkatkan kemampuan berbahasa anak, baik membaca, menulis, mendengarkan dan berbicara, selain keterbacaan ukurannya yang besar membuat media ini akan sangat membantu proses kegiatan belajar mengajar yang bermakna dan menyenangkan

Kata Kunci: Media kartu kosa kata, pembelajaran bahasa
\end{abstract}

\begin{abstract}
Vocabulary card media and language learning. Learning media plays an important role in the teaching and learning process in the classroom. The learning process cannot be separated from the use of media used by teachers in a continuous and comprehensive manner which will certainly support the professionalism of teachers, especially language teachers. It takes the skills of a language teacher in using vocabulary card media so that learning is interesting, innovative and fun. It takes teacher awareness always and familiar with learning media. Skillfully using vocabulary card learning media in the teaching and learning process is one way to support the professionalism of language teachers, especially at the early age and elementary school levels. If understood properly, actually vocabulary card media is the answer for language
\end{abstract}

p-ISSN 2648-8600

e-ISSN 2745-410X

Volume 4 Nomor 2 Desember 2021 
teachers to improve children's language skills, both reading, writing, listening and speaking.

Keywords: Vocabulary card media, language learning

\section{PENDAHULUAN}

Kegiatan pembelajaran bahasa melibatkan aspek bahasa, belajar bahasa, dan pembelajaran bahasa. Pengertian-pengertian di bawah ini akan mengkaitkan aspek- aspek tersebut untuk memahami tentang pembelajaran bahasa.

Pembelajaran bahasa harus melibatkan empat faktor, yakni guru, pengajaran bahasa, metode pengajaran bahasa, dan materi pelajaran. Empat faktor tersebut menjadi bagian terpenting dalam usaha membantu dan memudahkan proses belajar mengajara bahasa.

Guru merupakan faktor yang terpenting dalam proses permudahan dalam proses belajar. Karena guru merupakan fasilitator dalam proses pembelajaran yang memerlukan caracara atau meode dalam pembelajaran. Jadi, guru yang baik, pada umumnya selalu berusaha untuk menggunakan metode pengajaran yang efektif, serta memakai alat-alat media yang terbaik dalam melaksanakan pembelajaran bahasa. Pencarian metode yang paling efektif tetap saja dilakukan dari zaman ke zaman.

Dengan adanya perubahan teknologi yang semakin cepat, maka seorang guru bahasa harus memberikan dampak yang sangat kuat pada dunia pendidikan. Tentunya peran guru di zaman mutakhir ini sangat diperlukan. Selain mendidik, mengajar, membimbing, mengarahkan, melatih, menilai dan mengevaluasi siswa, guru juga harus berperan dalam meningkatkan motivasi belajar siswa.

Belajar dapat diartikan sebuah proses internal siswa dan pembelajaran merupakan kondisi eksternal belajar. Dari sisi siswa, belajar merupakan kegiatan peningkatan pengetahuan, sikap dan keterampilan menjadi lebih baik. Dari segi guru, belajar merupakan akibat tindakan pembelajaran maka timbul pertanyaan bagaimana cara guru meningkatkan proses pembelajaran sehingga siswa belajar secara berhasil. 
Guru merupakan insan yang menentukan penerapan strategi belajar mengajar di kelas. Tanpa guru, ideal dan bagusnya suatu strategi, maka strategi itu tidak mungkin dapat diterapkan. Guru harus memiliki paradigma dan menganggap mengajar hanya sebatas menyampaikan materi pelajaran akan berbeda dengan guru yang memiliki pemikiran mengajar adalah suatu proses pemberian bantuan kepada siswa. Tentunya, perbedaan tersebut akan mempengaruhi tindakan guru dalam proses belajar mengajar terjadi kepada siswa. Guru selalu dan berusaha untuk berbenah diri dan mampu membangkitkan semangat dan motivasi siswa. Bukankah motivasi menjadi salah satu aspek yang memegang peranan penting?

Dengan adanya motivasi siswa akan membantu guru dalam mudah tidaknya penggunaan media pembelajaran dalam proses belajar mengajar di kelas. Media pembelajaran merupakan alat bantu yang digunakan dalam menyalurkan pesan dari pengirim ke penerima pesan sehingga dapat terciptanya perhatian, minat, merangsang pikiran sebagai salah satu upaya menciptakan situasi dan kondisi pembelajaran yang efektif dan efisien sehingga tujuan pembelajaran tercapai.

Ketika proses pembelajaran terjadi, maka proses pembelajaran bahasa baik itu membaca, menulis, mendengar atau berbicara pun terjadi. Oleh karena itu dapat dikatakan dalam proses pembelajara merupakan proses kemampuan berbahasa dan berlangsung dalam suatu sistem, maka media pembelajaran menempati posisi yang sangat penting sebagai salah satu komponen sistem pembelajaran.

\section{MEDIA KARTU KOSA KATA DALAM PEMBELAJARAN BAHASA}

\section{Media Pembelajaran}

Media merupakan alat perantara yang digunakan seseorang dalam proses menyampaikan suatu pesan. Pendapat ini juga didukung oleh Azhar Arsyad (2013:3) yang menyatakan "Kata media berasal dari bahasa yang secara harfiah berarti 
“Tengah" perantara atau materi "Pengantar" atau pengantar pesan dan mengirim kepada penerima pesa."Media adalah komponen sumber belajar atau wahana fisik yang mengandung materi instruksional di lingkungan siswa yang dapat merangsang siswa untuk belajar.Pendapat tersebut didukung oleh Nushrotuddiniyah (2018:19) yang menyatakan bahwa "Media pembelajaran adalah segala sesuatu yang dapat digunakan untuk menyalurkan pesan dari pengirim ke penerimaan pesan sehingga dapat merangsang pikiran perasaan, perhatian, dan minat sebagai upaya menciptakan kondisi belajar yang efektif dsn efisien agar tujuan pembelajaran dapat dicapai dengan mudah.

\section{Media Kartu Kosa Kata}

$\begin{array}{rrr}\text { Pembelajaran } & \text { bahasa } & \text { perlu } \\ \text { dikembangkan } & \text { sejak } & \text { dini. }\end{array}$
Pembelajaran bahasa juga merupakan salah satu bagian yang wajib diajarkan mulai dari tingkat pendidikan usia dini hingga perguruan tinggi. Oleh karena itu, berdasarkan masalah-masalah yang ditemukan, perlu diadakan media pembelajaran bahasa yang mumpuni dapat meningkatkan daya kreatif dan semangat bahkan menyenangkan bagi siswa. Media kartu kosa kata menjadi salah satu alternatif pembelajaran yang digunakan untuk meningkatkan hasil belajar bahasa di sekolah.

Seiring dengan adanya media kartu kosa kata merupakan media media cetak, media berbasis cetak yaitu kertas tebal berbentuk persegi panjang (untuk berbagai keperluan, hampir sama dengan karcis). Kosakata adalah perbendaharaan kata. Apabila dua kata digabungkan maka kartu kosakata adalah kertas tebal berbentuk persegi panjang yang bertuliskan kata.

Media kartu kosakata merupakan teknik pembelajaran kata melalui kartu. Kartu berukukran 5 x 7 inchi (1 inchi 2,54) yang di dalamnya tertulis kata tunggal. (Jerrold E. Kemp and D Smellie: 1989). Teknik pembelajaran ini dapat dilakukan secara individu dan kelompok. Penerapan media kartu kosa kata dalam 
pembelajaran bahasa yaitu dalam membaca, menulis, mendengar dan berbicara sangat membantu proses perkembangan kognitif anak. Tentunya, pembelajaran kartu kosakata bertujuan agar peserta didik dapat dengan mudah, senang dan bergairah dalam memahami kata melalui proses yang dilaluinya sendiri.

Penggunaan kartu kosakata sebagai media dalam proses pembelajaran memiliki keistimewaan yang tidak dimiliki oleh media lain, yaitu 1) sebagai media yang efektif untuk menumbuh kembangkan minat anak dalam pembelajaran, 2) menjadikan anak terlibat dan berpartisipasi aktif dalam proses pembelajaran, 3) anak yang menggunakan media kartu kosakata lebih cepat mengingat gambar karena karakter dan warna gambar yang menarik.

Ketika seorang anak belajar menggunakan kartu kosakata maka gelombang otak akan bekerja, ada empat kondisi gelombang otak yaitu gelombang delta, theta, alfa dan beta.
Setiap gelombang memiliki karakteristik khusus: 1) gelombang delta berkisar antara $0.1-4$ cps. Delta merupakan frekuensi dan pokirann nirsadar pada saat tidur. 2) gelombang theta berkisar antara $4-6 \mathrm{cps}$, gelombang ini dihasilkan oleh pikiran bawah sadar, theta muncul saat bermimpi dan saat terjadi rapid eye movement (Portilla et at:2008) pikiran alam bawah sadar menyimpan memori jagka panjang dan juga merupakan gudang inspirasi kreatif. 3) gelombang alfa dengan besaran sekitar 8-12 cps, dalam kondisi kreatif. 3) gelombang alfa dengan besara sekitar 8-12 cps, dalam kondisi normal antara akitivitas dan kondisi agar santai. Manfaat gelombang alfa adalah yang paling penting sebagai jembatan penghubung antara pikiran sadar dengan bawah sadar. 4) gelombang beta besaran antara 12-28 cps, saat aktif berfikir dan melakukan kegiatan fisik maka kondisi otak berada di gelombang beta yang merupakan jenis gelombang otak yang paling tinggi frekuensinya. (Yulanti Siantayani:2010) 
Belajar dengan kartu kosa kata otomatis menggunakan mata sebagai alat indera yang digunakan maka mata memiliki peran penting dalam proses pembelajaran ini. Berikut cara kerja mata benda-benda di luar mata mengirimkan cahaya masuk dalam mata dengan menembus kornea, aqueous humor, melalui pupil, lensa kristanila, vitreous humor setelah mengalami beberapa kali pembiasaan, sampailah pada retina (sebagai layar penangkap bayangan, bayangan pada retina terbalik dan lebih kecil) bayangan tersebut dikirim ke pusat penglihatan (otak melalui saraf optic di otak) bayangan tersebut diartikan dapat melihat benda tersebut (Steven M. Lavella: 2016).

Menurut Bruner ada 3 tingkatan benar yaitu pengalaman langsung, pengalaman gambar dan pengalaman abstrak (Andoyo Sastromiharjo:2008). Tingkatan pengalaman pemerolehan hasil belajar seperti itu digambarkan oleh Dale sebagai suatu proses berbicara. (Cecep Kustandi:2011). Materi yang ingin disampaikan dan yang diinginkan anak agar dapat menguasai disebut sebagai pesan.

Proses pembelajaran dapat berhasil dengan baik bila anak diajak untuk memanfaatkan semua alat inderanya. Guru berupaya untuk menampilkan rasangan yang dapat diproses dengan inderanya. Semakin banyak alat indera yang digunakan untuk menerima dan mengelola informasi, semakin besar kemugkinan informasi tersebut dan dipahami serta dipertahankan dalam ingatan.

Keberhasilan sebuah tindakan di dalam kelas sangat tergantung pada kemampuan guru dalam memberikan stimulasi. Kemampuan berbicara menuntut guru memiliki suara yang jelas tidak ada kecatatan dalam bunyi hasil penelitian ini menunjukkan bahwa guru dengan vocal yang jelas dan tegas menentukan keberhasilan. Ada beberapa hal yang harus diperhatikan guru pertama mengucapkan dengan lantang dimana guru meminta anak mengulang kata yang diucapkan sambil mengoreksi kesalahan pengucapan anak, kedua adalah pengulangan 
dimana anak diminta untuk mengulang setelah pengucapan yang benar.

\section{Pengembangan Kartu Kosa Kata}

Adapun yang perlu diperhatikan dalam pengembangan kartu kosa kata sebagai berikut:

1. Dengan adanya kartu kosa kata maka sangat dibutuhkan dalam proses belajar mengajar di kelas. Media kartu kosa kata menjadi jawaban bagi guru-guru khususnya guru bahasa Indonesia untuk menciptakan proses belajar mengajar yang menarik, inovatif dan menyenangkan. Maka media kartu kosa kata ini layak untuk dikembangkan.

2. Secara garis besar, media kartu kosa kata sangat membantu guruguru bahasa dalam mengajarkan kosa kata kepada anak usia dini dan sekolah dasar, selain warna yang sangat menarik kartu ini memiliki ukuran yang besar sehingga dapat ditempel pada papan tulis. Media kartu kosa kata dengan ukuran besar memungkinkan siswa melihat lebih jelas lagi. Maka media ini layak untuk dikembangkan.

3. Secara umum media kartu kosa kata menjadi jawaban bagi guru bahasa untuk meningkatkan kemampuan berbahasa anak, baik membaca, menulis, mendengarkan dan berbicara, selain keterbacaan ukurannya yang besar membuat media ini akan sangat membantu proses kegiatan belajar mengajar yang bermakna dan menyenangkan. Maka media ini layak untuk dikembangkan.

\section{PENUTUP}

Kemampuan guru bahasa dalam merencanakan, mengadakan, menggunakan media kartu kosa kata yang sesuai dengan kebutuhan peserta didik akan memberikan dampak yang besar terhadap hasil belajar siswa. Dalam penggunaan media kartu kosa kata ini, dilakukan secara kontiunitas serta diperlukan analisis yang komprehensif dengan memperhatikan berbagai aspek yang dapat mempengaruhi keberhasilan pembelajaran. Akhirnya, guru bahasa 
diharapkan mampu mengenal kelebihan dan pengembangan media kartu kosa kata termasuk perbaikan media kartu kosa kata yang digunakan dengan mengantisipasi kelemahan yang timbul apabila media ini digunakan dalam pembelajaran bahasa di kelas.

\section{DAFTAR PUSTAKA}

Aini, N.J., dan Shahverdian. 2007. Tahap Penggunaan Media Komputer (perisian Kursus dan Internet) Dalam kalangan Guru-guru Sains dan Matematika Daerah Temerloh. Edu 5300 Universiti Putra

Malaysia.

Azhar, A. 2009. Media Pembelajaran. Jakarta: Raja Grafindo

Danim, S., 2002. Inovasi Pendidikan Dalam Upaya Profesionalisme Guru. Bandung: Pustaka Setia.

Daryanto. 2013. Media Pembelajaran (Peranannya Sangat Penting Dalam Mencapai Tujuan Pembelajaran). Yogyakarta: Gava Media

p-ISSN 2648-8600 e-ISSN 2745-410X Volume 4 Nomor 2 Desember 2021

Djohar. 2006. Guru Pendidikan dan Pembinaannya (Penerapannya dalam pendidikan dan $U U$ Guru). Yogyakarta: Grafika

Rumampuk, D.B. 1998. Media Instruksional IPS. Jakarta: Departemen Pendidikan dan Kebudayaan

Sandewita, N. 2014. Media Pembelajaran 3Dimensi. (online).Tersedia: http://www.v h asande.blogspot.com/2014/04/

$\mathrm{m}$ edia-pembelajaran-3dimensi.html?m=1

Supardi, Kanisius. 2017. Media Visual dan Pembelajaran IPA di Sekolah Dasar. Jurnal inovasi Pendidikan Dasar Volume

1 No, 2 tahun 2017

Sanjaya, Wina. 2016. Strategi pembelajaran Berorientasi Standar Proses Pendidikan. Jakarta: Kharisma Putra Utama.

Sardiman. 2016. Interaksi dan Motivasi Belajar Mengajar. Jakarta: Rajawali.

Sastromiharjo, Andoyo. 2008. Media dan Sumber Pembelajaran.

Bandung: UPI

Siantayani, Yulanti. 2010. Misteri

Aktivitas OtakTengah.

Semarang: Kriteria Publisher 
Purba, Nancy Angelia. 2016.

Penerapan Teknik Rekayasa

Teks dengan Media

Komputer dalam

Meningkatkan Kemampuan

Menulis Puisi. Vol. 6 No. 3

Desember 2016

Purba, Nancy Angelia. 2021. Meningkatkan hasil belajar siswa pada pokok bahasan menulis puisi dengan menggunakan

media visual tiga dimensi (3D) kelas V SD Negeri 091281 batu IV. Jurnal Aquinas

Vol. Vol. 4 No. 2 (2021): $\quad$ Juli 2021

Purba, Natalina. 2021. Pengembangan Media Kartu Kosakata untuk Peningkatan Kemampuan Berbicara Anak Tunagrahita Mampu Latih. Bandung: Widina Bhakti Persada 